\title{
Anti-allergic activities of Umbelliferone against histamine- and Picryl chloride- induced ear edema by targeting Nrf2/iNOS signaling in mice
}

Younas $^{1 \dagger}$, Ashrafullah Khan ${ }^{1 \dagger}$, Omer Shehzad ${ }^{2}$, Eun Kyoung Seo ${ }^{3}$, Alev Onder ${ }^{4}$ and Salman Khan ${ }^{1 *}$ (D)

\begin{abstract}
Background: The current study was aimed to investigate the anti-allergic activities of the Umbelliferone (UMB) against the acute Histamine and chronic Picryl chloride (PiCl)-induced allergy in mice. UMB is a coumarin derivative (isolated from Angelica decursiva) found in various parts of the plants such as flowers, roots and, stems isolated from the plants of Umbelliferae family.

Methods: The UMB (1, 10,50 mg/kg) was administered intraperitoneally (i.p) half an $\mathrm{h}$ before or $2 \mathrm{~h}$ after the induction of allergic ear edema. The acute ear edema was induced by histamine (intradermally, i.d), while the chronic ear edema was induced by painting the $\mathrm{PiCl}$ (sensitized with the toluene) on the ear. The antioxidants and oxidative stress markers were assessed. The histological changes were assessed using Hematoxylin and eosin ( $H$ and E) and giemsa staining. The immunohistochemistry studies were performed to assess the expression of the nuclear factor erythroid 2-related factor 2 (Nrf2) and inducible nitric oxide synthase (iNOS). The data was analyzed using one-way ANOVA tests followed by Tukey's test with $p<0.05$ was chosen as criteria for statistical significance.

Results: UMB treatment markedly reduced the allergic ear edema and ear weight compared to the negative control. Furthermore, the UMB attenuated the oxidative stress markers, while induced the antioxidants enzymes. Similarly, the UMB treatment significantly attenuated the serum immunoglobulin E (IgE) level. The UMB treatment markedly improved the histological parameters using $\mathrm{H}$ and $\mathrm{E}$ staining and Giemsa staining. The UMB administration induced the Nrf2 expression, while attenuated the iNOS expression. Furthermore, the computational analysis was performed to assess the interaction of the UMB with the various protein targets and to determine the mechanism of interaction with the target proteins.
\end{abstract}

Conclusion: In conclusion, the UMB treatment significantly alleviated the allergic symptoms, attenuating the oxidative stress, improved the histological features using in vivo and computational approaches.

Keywords: Umbelliferone, Picryl chloride, Oxidative stress, Antioxidant, Inflammation

\footnotetext{
* Correspondence: skhan@qau.edu.pk; udrsalman@gmail.com

${ }^{\dagger}$ Both the author contributed equally to this work.

'Pharmacological Sciences Research Lab, Department of Pharmacy, Faculty

of Biological Sciences, Quaid-i-Azam University Islamabad, Islamabad,

Pakistan

Full list of author information is available at the end of the article
}

(c) The Author(s). 2021 Open Access This article is licensed under a Creative Commons Attribution 4.0 International License, which permits use, sharing, adaptation, distribution and reproduction in any medium or format, as long as you give appropriate credit to the original author(s) and the source, provide a link to the Creative Commons licence, and indicate if changes were made. The images or other third party material in this article are included in the article's Creative Commons licence, unless indicated otherwise in a credit line to the material. If material is not included in the article's Creative Commons licence and your intended use is not permitted by statutory regulation or exceeds the permitted use, you will need to obtain permission directly from the copyright holder. To view a copy of this licence, visit http://creativecommons.org/licenses/by/4.0/. The Creative Commons Public Domain Dedication waiver (http://creativecommons.org/publicdomain/zero/1.0/) applies to the data made available in this article, unless otherwise stated in a credit line to the data. 


\section{Backgroud}

Skin is the first and foremost principal barrier to external injury or infectious agent [1]. Usually, the skin offer protection against infectious agents and other harmful agents by synthesizing various chemicals without disturbing the normal tissue [1,2]. However, disturbance of the immune system may worsen the pre-existing skin inflammatory disease like psoriasis and atopic dermatitis $[1,2]$. Atopic dermatitis is an allergic inflammatory condition affecting mainly the keratinocytes of the skin characterized by pruritus, chronic eczematous plaque and relapse upon exposure to an antigen [2]. The inflamed skin shows different histological parameters like scaling, dryness, skin eruption and papules involving eosinophils, mast cells and other inflammatory cells. The disparity of $\mathrm{T}$ helper 1 (Th1) and T helper 2 (Th2) cells have been reported in atopic dermatitis with the dominancy of the $\mathrm{T}$ helper 2 responses, which leads to the increase production of IgE antibodies [2, 3].

The pro-inflammatory mediators (IL-1 $\beta$, IL- 6 and TNF- $\alpha$ ) and oxidative stress plays a critical role in the development of allergic inflammatory disorders. During allergic conditions the NO production is significantly enhanced and its production is regulated by the iNOS genes $[2,3]$. The NO production is directly associated with the severity of the allergic symptoms. Increase in the production of $\mathrm{NO}$ and oxygen free radicals which may further enhance the vasodilation and cytotoxicity leading to allergic ear edema [2]. The Nrf2 is an important signaling pathway involved in the regulation of oxidative stress and induction of antioxidants enzymes [4]. The Nrf2 remains dormant within the cytosol under the inhibitory influence of Kelch-like ECH-associated protein 1 (Keap1). During basal conditions small only amount of Nrf2 is released and undergoes Proteasomal degradations. During inflammatory conditions, the Nrf2 becomes free from the inhibitory influence of the Keap1 and translocate to the nuclei to interact with the concerned genes [4]. The Nrf2 interacts with the antioxidants response element (ARE) and induces the antioxidants enzymes such as Heame oxygenase-1 (HO-1), Superoxide dismutase (SOD), Catalase, reduced glutathione (GSH), and Glutathione S-transferase (GST) [4]. The antioxidants thus produced neutralizes the oxidative stress markers such as malondialdehyde (MDA) and glutathione peroxidase (GPx) [3]. Similarly, the Nrf2 signaling also inhibit the production of the pro-inflammatory cytokines and attenuate the inflammation $[3,5]$.

The therapeutic approaches available for treating allergic dermatitis are associated with various side effects like ulcer, sedation and palpitation $[5,6]$. The natural products are cheap and important sources of the new drug development and many drugs from natural sources are currently in clinical practice $[3,6,7]$. The Umbelliferone is 7-hydroxycoumarin isolated from the $A$. decursiva and found in various parts of the plants such as leaf, roots and fruits of Umbelliferae family. Chemically it is benzopyrone in nature and reported for a wide range of biological activities [8]. The Umbelliferone have been reported for the anti-inflammatory and antioxidants activity in a chronic animal model of alcohol fed rats and streptozotocin-induced diabetes [4, 9]. Similarly, the anti-cancer and anti-apoptotic activity of UMB have also been documented in the various model of carcinogenesis i.e. colon, hepatic and renal cancer [10-12]. Furthermore, the Umbelliferone have also been implicated in the amelioration of the LPS-induced bone loss and osteoclastogenesis via multiple signaling mechanisms [13, 14]. The ischemic-reperfusion myocardial injury was prevented by the Umbelliferone treatment by suppressing the NLPR3 inflammasome and inducing PPAR- $\gamma$. The Umbelliferone have also been reported for antiarthritic and hepatoprotective activity pre-clinically [15, 16]. Based on the previous reports, it was anticipated that Umbelliferone treatment will ameliorate the allergic ear edema induced by the $\mathrm{PiCl}$ (sensitized with Toluene) and Histamine. Furthermore, in the present study, it was aimed to explore the underlying mechanism of Umbelliferone against the $\mathrm{PiCl}$ and Histamine-induced allergy.

\section{Methods}

\section{Chemicals and reagents}

The chemicals and reagents used in the current study include $\mathrm{UMB}, \mathrm{PiCl}$, histamine, ketamine, dimethylsulphoxide (DMSO), Toluene, dexamethasone, acetone, ethanol, 5,5'-dithiobis-(2-nitrobenzoic acid (DTNB), 1chloro-2,4-dinitrobenzene (cDNB), phenylenediamine and Tris- $\mathrm{HCl}$ were obtained from the Sigma Aldrich (Sigma Aldrich, USA). The avidin-biotin complex $(\mathrm{ABC})$, proteinase- $\mathrm{K}, 3,3$-diaminobenzidine $(\mathrm{DAB})$, $\mathrm{xy}$ lene, and mounting media were purchased from the Santa Cruz (Santa Cruz, Inc). All the chemical and reagents used in the present study were of analytical grade. The $\mathrm{PiCl}$ solution was prepared in acetone and ethanol at 3:1 ratio, respectively.

\section{Plant materials}

The Umbelliferone is 7-hydroxycoumarin in nature and mainly found in the plants of Umbelliferae family $[3,8]$. The plant of $A$. decursiva was collected and identified at Korean Research Institute of Bioscience and Biotechnology, Republic of Korea (Lot\#012-043, 2006) and the voucher specimen (2006 CHOI-Angelica02) was deposited. The Umbelliferone was isolated and characterized at Pukyong National University (Department of Food and Life Sciences), Busan, Republic of South Korea and $[8,13]$. The UMB and dexamethasone was dissolved in the normal saline using $2 \%$ DMSO and administered by 
the intraperitoneal route (i.p) as reported previously [16-18].

\section{Animals}

Male and female albino BALB/c mice (5-7 weeks old) weighing 28-36 g were procured from the national institute of health (NIH) Islamabad. The animals were acclimatized to experimental environment for 7 days before the study and the activities were performed in the pathogen free area i.e. lab of pharmacology, department of pharmacy. The animals were provided $12 \mathrm{~h}$ of light/dark cycle, room temperature of $23 \pm 0.5$ and relative humidity of $55 \%$. The animals were provided free access to water and food. All the procedure were performed according to guidelines of the animal ethical committee of Quaid-i-Azam University, Islamabad (\#BEC-FBSQAU2019-181). During the whole study, great care was initiated to avoid any harm to the experimental animal and number of animals were kept as minimum as possible. During the current study, fresh animals were procured and used once [19].

\section{Grouping and study protocols}

Animals were randomly assigned into six groups randomly $(n=5)$ such as normal control (normal saline 0.9\% with $2 \%$ DMSO), positive control (dexamethasone $10 \mathrm{mg} / \mathrm{kg}$ ), negative control (histamine $10 \mathrm{mg} / \mathrm{kg}$ in case of acute study, while $\mathrm{PiCl}$ (sensitized with Toluene in chronic study)) and UMB (in three different doses i.e. 1, 10 and $50 \mathrm{mg} / \mathrm{kg}$ ). $\mathrm{PiCl}$ was painted topically on right ear of each mouse through micropipette, while UMB was administered through i.p route. Normal control group was treated by painting normal saline on the right ear $[19,20]$. For sampling, the animals were anesthetized using combination of Xylazine and Ketamineinjection (16 mg $+60 \mathrm{mg}$, i.p) to avoid distress and discomfort to the animals during sampling. When the sampling was performed the animals were euthanized using $\mathrm{CO}_{2}$ chamber and the animals death was confirmed by assessing the heart rate, eye reflexes and respiration [21]. The institutional ethical committee regulated the overall process of euthanasia.

\section{Induction of ear edema by histamine (acute study)}

The acute ear edema was induced by injecting the histamine intradermal (i.d) in both male and female mice. The edema was induced in the right ear lobe of each group by administering $5 \mu$ l of histamine using a special 29 gauge hypodermic needle, while the left ear received $5 \mu \mathrm{l}$ of saline topically. After $15 \mathrm{~min}$ the positive control group was treated with dexamethasone $(10 \mathrm{mg} / \mathrm{kg}$, i.p), while the treatment group received $\operatorname{UMB}(1,10$ and 50 $\mathrm{mg} / \mathrm{kg}$, i.p). The ear edema was determined with thickness gauge meter after $2 \mathrm{~h}$ of histamine administration as described $[19,20]$.

\section{$\mathrm{PiCl}$ (sensitization of allergy with toluene) multiple administration induced allergy}

Cyclophosphamide was injected subcutaneously (s.c) at a dose of $(150 \mathrm{mg} / \mathrm{kg})$ body weight for inducing blood eosinophilia in both male and female mice as described previously [20]. After 2 days i.e. on day 0 the right ear lobe of each group except normal control, were painted by $50 \mu \mathrm{l}$ of $7 \%(\mathrm{w} / \mathrm{v}) \mathrm{PiCl}$ solution (3:1 in acetone:ethanol solution) for sensitization. Following initial treatment, the same groups were treated twice with $20 \mu \mathrm{l}$ of Toluene solution at the same site on day 5, 10 and 12. Ear edema was measured by dial thickness meter either half an $\mathrm{h}$ before or $2 \mathrm{~h}$ after inducing allergic disease [22]. On day 12 , the both male and female mice were anaesthetized with the combination of xylazine and ketamine (16 and $60 \mathrm{mg} / \mathrm{kg}$ respectively, i.p) and the whole ear was collected [20, 23]. From the whole ear, 5-6 mm diameter was obtained via metallic punch and weighed on an electronic weight balance for determination of ear mass (chronic study only) [20, 22]. The Fig. 1 shows the schematic representation of the study.

\section{Assessment of ear edema}

Ear edema in all the treated groups (both male and female) were measured with Oditest dial gauge caliper either half an $\mathrm{h}$ before or $2 \mathrm{~h}$ after induction of allergic edema by histamine (acute study) or PiCl-induced sensitized with Toluene (chronic study) as reported previously [20].

\section{Determination of skin severity scoring}

The severity of allergic ear edema was evaluated in both male and female on every 3rd day by scoring the symptoms following induction of allergic edema [24]. Every symptom was graded $(0=$ no symptom; $1=$ mild; $2=$ moderate; 3 = severe) based on evaluation of skin dryness, eruption and wound appearance on right ear of each group reported previously [24].

\section{Determination of mice weight}

The changes in the body weights of all the recruited groups were determined during the whole study after every 3 days for 12 days period. For the determination of the mice weights, the mice were placed on a digital weighing balance $[25,26]$.

\section{Weight lifting and light chain assay}

To assess the effect of UMB treatment on the muscle coordination and strength following PiCl-induced allergy, weight lifting and inverted mesh screen assay was performed in both male and female as reported 


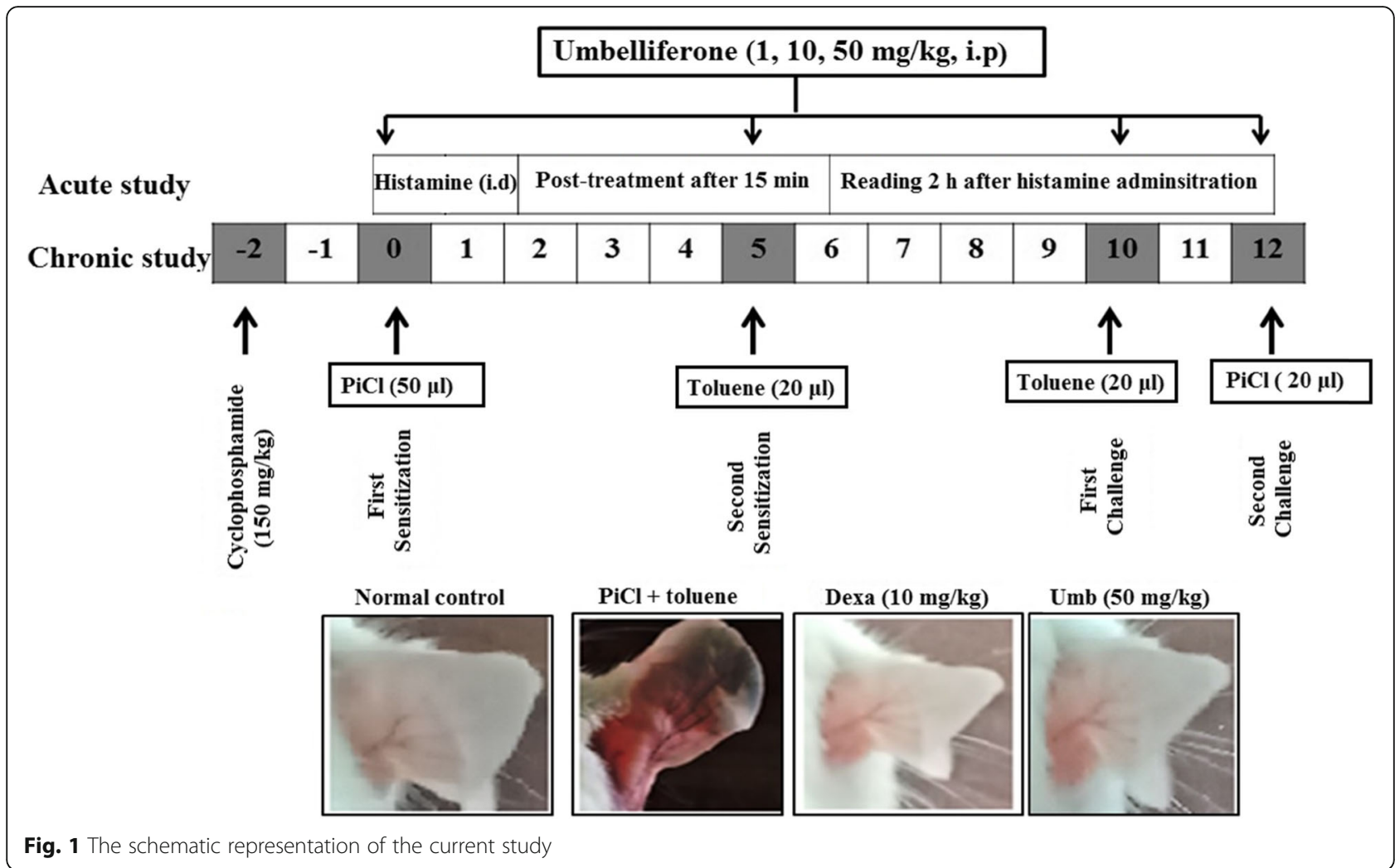

previously [26]. The animals were allowed to lift the weight in decreasing order for $3 \mathrm{~s}$ and quantify the maximum weight lifted by the mice as reported [26]. Similarly, for the assessment of inverted mesh assay animals were placed on the mesh and inverted to assess the strength of animal holding with the mesh screen as reported [26].

\section{Determination of biochemical and hematological parameters}

The effect of the UMB treatment on vital organs such as liver and kidney were evaluated by observing the biochemical parameters like alanine aminotransferase (ALT), aspartate aminotransferase (AST), bilirubin and creatinine level in plasma following $\mathrm{PiCl}$-induced allergic edema [27, 28]. Similarly, the effect of UMB treatment on the hematology (total leukocytes count and differential leukocytes) was assessed following $\mathrm{PiCl}$-induced allergic edema [27]. Furthermore, the changes in the level of serum IgE in both acute and chronic study was measured by an ELISA kit according to manufacturer instructions (Abcam, USA) [26, 28, 29].

\section{Determination of antioxidants}

The influence of UMB on various antioxidants like reduced Glutathione (GSH), Glutathione S-transferase (GST), Catalase and Superoxide dismutase (SOD) were noted by the method as described previously [30]. The reduced Glutathione (GSH) was performed by taking $100 \mu \mathrm{l}$ of supernatant obtained from previously homogenized tissue in a 96 well tube [30]. To make the final volume up to $3 \mathrm{ml}, 0.5 \mathrm{ml}$ DTNB was added to $2.4 \mathrm{ml}$ of phosphate buffer solution with $0.1 \mathrm{ml}$ of tissue supernatant [31]. The absorbance was recorded at a wavelength of $412 \mathrm{~nm}$. Similarly, the GSH assay was performed by mixing of $0.1 \mathrm{ml}$ of supernatant, cDNB and $0.1 \mathrm{M}$ phosphate buffer $(\mathrm{pH}=6.5)$ to make the final volume up to $3 \mathrm{ml}$. The absorbance was recorded at a wavelength of $314 \mathrm{~nm}$ as described previously [31]. This Catalase assay was performed by taking $3 \mathrm{ml}$ of $\mathrm{H}_{2} \mathrm{O}_{2}$ phosphate buffer in a cuvette with $40 \mu \mathrm{l}$ of tissue enzyme extract and the absorbance was recorded at $240 \mathrm{~nm}$ [30, 31]. Similarly, SOD assay was performed by the mixing of $10 \mu \mathrm{l}$ of sample with the $50 \mathrm{mM}$ Tris-EDTA buffer $(\mathrm{pH}=8.5)$ and $24 \mathrm{mM}$ Pyrogallol to make the final volume up to $0.2 \mathrm{ml}$. Enzyme activity was measured at 420 $\mathrm{nm}$ and expressed as unit/mg protein [30-32].

\section{Determination of LPO, MPO and EPO}

Lipid peroxidation product i.e. MDA was determined in all the study groups following histamine and $\mathrm{PiCl}$ induced ear edema as reported [31]. The reaction mixture consisting of TCA (trichloroacetic acid), TBA (thiobarbituric acid), ferric chloride $(\mathrm{FeCl} 3)$ and study 
samples [31]. The reaction mixture was boiled at $100{ }^{\circ} \mathrm{C}$ and analyzed using microplate reader at $420 \mathrm{~nm}$. Furthermore, the MPO (Myeloperoxidase) assay was determined in ear homogenate as described somewhere else [33]. The reaction mixture was obtained by the addition of o-dianisidine $(16.7 \mathrm{mg})$ in $90 \mathrm{ml}$ distilled water to which $10 \mathrm{ml}$ of $500 \mathrm{mg}$ CTAB (previously dissolved in PBS) was added. Thereafter, $50 \mu \mathrm{l}$ of $\mathrm{H}_{2} \mathrm{O}_{2}$ was added to the final reaction mixture along with $7 \mu$ l of tissue sample. The Activity was measured by the changes in optic density at $450 \mathrm{~nm}$ using microplate reader. The EPO serves as a marker of eosinophilic infiltration and increase concentration have been reported during allergic conditions [33]. The effect of UMB treatment on the EPO activity following chronic $\mathrm{PiCl}$-induced ear edema was evaluated as reported previously [33, 34].

\section{Determination of NO level}

This effect of the UMB treatment was assessed on the $\mathrm{NO}$ production following histamine and $\mathrm{PiCl}$-induced ear edema as reported [35]. The NO production was determined in both plasma and tissue homogenate using the Griess reagent method as reported [35]. The NO production was recorded as $560 \mathrm{~nm}$ using a microplate reader [35].

\section{Histological analysis}

The $\mathrm{H}$ and $\mathrm{E}$ staining was performed to assess the histological changes in ear tissue following PiCl-induced ear edema as reported previously [36, 37]. Increase or decrease in the number of various inflammatory cells, changes in cartilaginous diameter and edema (epidermal and dermal) was evaluated in all the treated groups [36]. Similarly, the Giemsa staining was performed to assess the changes in eosinophilic infiltration in ear tissue of all the treated groups. The Giemsa stained images were visualized with the help of light microscope (400X magnification) [36].

\section{Immunohistochemistry of Nrf2 and iNOS}

The immunohistochemistry assay was performed to assess the Nrf2 and iNOS expression following histamine and $\mathrm{PiCl}$-induced ear edema in all the treated groups [38]. The paraffin embedded tissue were deparraffinized in the xylene, ethanol and then washed with the distilled water [37]. Following deparraffinization, the tissues were treated with the proteinase-k, normal goat serum and primary antibodies (kept overnight to allow the interaction of the antibodies with the tissues). Next day, the primary antibodies were washed with PBS and tissue were treated with secondary antibodies [38]. The avidinbiotin complex was applied $2 \mathrm{~h}$ after incubation with secondary antibodies and thereafter, the slides were treated with DAB solution as reported previously [38].
The images were then analyzed with microscopes, while the Nrf2 and iNOS expression level was quantified using Image_J software [37].

\section{Docking analysis}

The molecular docking analysis was performed to assess the interaction of the UMB with the IL- $6, \mathrm{IL}-1 \beta$, TNF- $\alpha$, IgE, iNOS and Nrf2 using autodock vina [39]. The IL-6, IL-1 $\beta$, TNF- $\alpha$, IgE, iNOS and Nrf2 proteins were downloaded from the Protein data bank (PDB) [39]. The ligand was prepared using Chemdraw_14.0 and saved as PDB format. The results were visualized using discovery studio visulaizer_16 and protein ligand interaction profiler online server $[39,40]$.

\section{Validation of docking}

The docking process of the UMB with the studied protein was validated and the root mean squared deviation (RMSD) was determined using LigRMSD software. The co-crystalized ligand was extracted and redocked with same protein and the RMSD value was calculated [39, 40].

\section{Pharmacokinetic analysis of Umbelliferone}

The pharmacokinetics analysis of the Umbelliferone was performed to determine the pharmacokinetic behavior of the UMB [39, 40]. The Swiss target prediction software (http://www.swissadme.ch/index.php) was used to assess the ADME (absorption, distribution, metabolism and excretion), bioavailability, physicochemical characteristics, lipophilicity and drug likeness behavior was analyzed as reported previously [39, 40].

\section{Statistical analysis}

Result obtained was expressed as mean \pm standard deviation. One way ANOVA test was performed followed by Post-hock test. $P$ value $<0.5$ was considered as criteria of statistical significance. \#\#\#P<0.001 indicates significant difference of negative control group. The Sigmaplot version_12 was used to plot the results of the study.

\section{Results}

\section{Ear edema}

The ear edema was determined in all the treated groups following histamine and $\mathrm{PiCl}$ administration. The negative control (histamine and $\mathrm{PiCl}$ treated groups) showed significant increase in the ear edema in both male and female mice. However, the UMB treatment dose dependently attenuated $(P<0.05)$ the ear edema in both acute histamine and chronic $\mathrm{PiCl}$-induced models. Similarly, the dexamethasone treatment also reduced the ear edema and hence, inflammation compared to the negative control as shown in Fig. 2. 


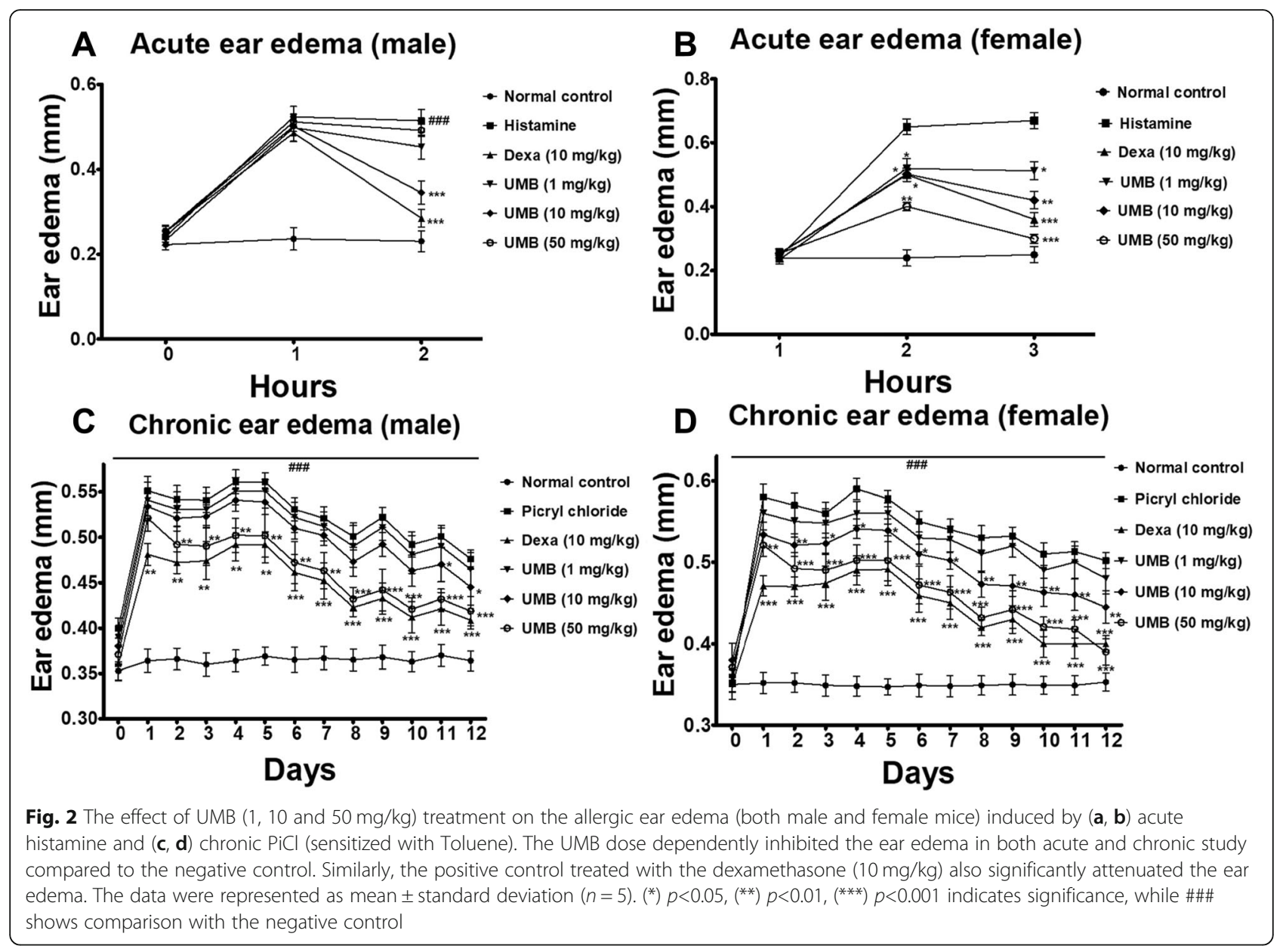

\section{Skin severity scoring}

Topical application of $\mathrm{PiCl}$ (sensitized with Toluene) showed an increase in skin severity of the negative control group (in both male and female mice). However, a more significant $(P<0.001)$ reduction in the skin severity score was observed in the UMB $(50 \mathrm{mg} / \mathrm{kg})$ treated group as compared to the negative control. Furthermore, dexamethasone $(10 \mathrm{mg} / \mathrm{kg})$ treated group also showed significant reduction $(P<0.001)$ in the ear edema as shown in Fig. 3.

\section{Ear weight}

The negative control ( $\mathrm{PiCl}$ sensitized with the Toluene) showed significant increase in the ear weight, however, the UMB treated group showed significant $(P<0.05)$ decrease in the ear weight compared to the negative control (in both male and female mice) as shown in Fig. 3.

\section{Mice weight}

The weight changes in all the treated groups were assessed in case of chronic study ( $\mathrm{PiCl}$ sensitized with Toluene) and the effect of the UMB treatment was evaluated (in both male and female mice). All the recruited groups treated group showed no changes in the body weights as shown in the Fig. 4.

\section{Inverted mesh screen and weight lifting assay}

The muscle strength and coordination assay was performed to investigate the effect of the UMB treatment on muscle strength and coordination following allergy induction with the $\mathrm{PiCl}$ [41]. The muscle strength was determined by the ability of the mice to hold the chain for $3 \mathrm{~s}$ [41]. Similarly, the inverted mesh screen test was also used to assess the muscle strength and coordination. However, the result showed no significant changes in the muscle strength and coordination as shown in the Fig. 4.

\section{Effect of UMB on biochemical and hematological parameters}

The UMB treatment showed marked $(P<0.05)$ improvement in the hematological parameters compared to the negative control as shown in the Table 1. Similarly, the biochemical parameters such as liver function tests (LFTs) and renal function tests (RFTs) were significantly alter by the UMB treatment as shown in the Table 2 . 


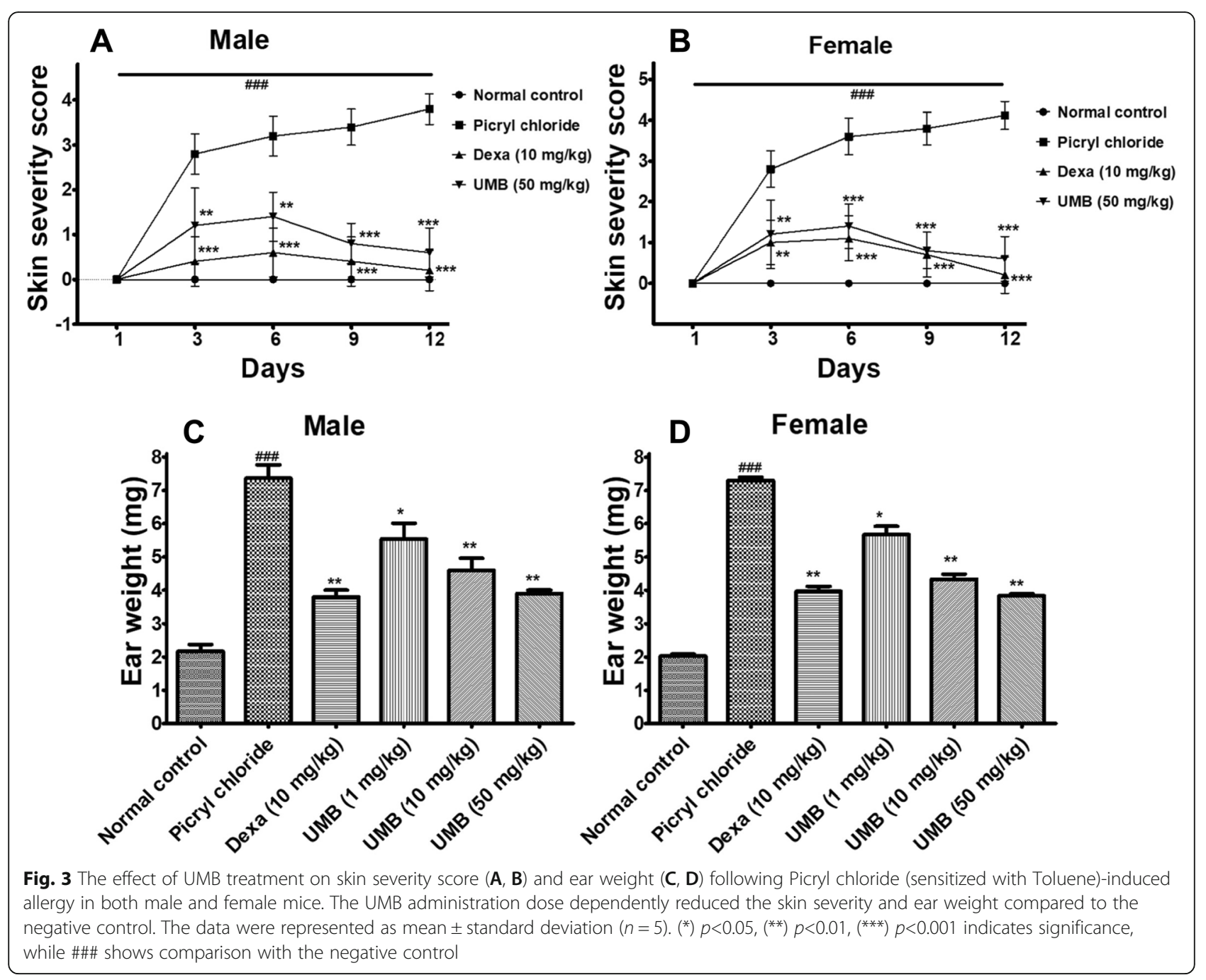

The UMB treatment significantly attenuated the serum IgE level using ELISA kit compared to the negative control as shown in the Fig. 5.

\section{Effect of UMB on antioxidants and oxidative stress markers}

The negative control groups showed a sharp reduction in the antioxidants enzymes such as GST, GSH, Catalase and SOD in the ear homogenate, however, the UMB treatment significantly enhanced the antioxidants enzymes as shown in the Fig. 7. Furthermore, the effect of the UMB treatment was also studied on the oxidative stress markers such as MDA following allergy induction with the PiCl. The UMB treatment significantly attenuated the production of the MDA i.e. the product of the lipid peroxidation compared to the negative control Fig. 8.

\section{Effect of UMB on NO production}

The concentration of $\mathrm{NO}$ was found higher in tissue homogenate of negative control group following induction of ear edema, however, the UMB treatment markedly attenuated the NO production compared to the negative control. Similarly, the positive control treated with the dexamethasone also markedly attenuated the NO production in both plasma and ear homogenate compared to the negative control as shown in Fig. 8.

\section{Effect of UMB on MPO activity}

The MPO activity (indirect marker of neutrophilic infiltration) was significantly raised in the ear homogenate of the negative control group. However, the UMB $(50 \mathrm{mg} /$ $\mathrm{kg}$, i.p) treated group showed a marked reduction in the MPO activity in the ear homogenate in contrast to the negative control. Similarly, the dexamethasone also remarkably attenuated the MPO activity compared to the negative control as shown in Fig. 8.

\section{Effect of UMB treatment on EPO activity}

Similarly, the EPO assay (an indirect indicator of the eosinophil infiltration) was performed to assess the effect 


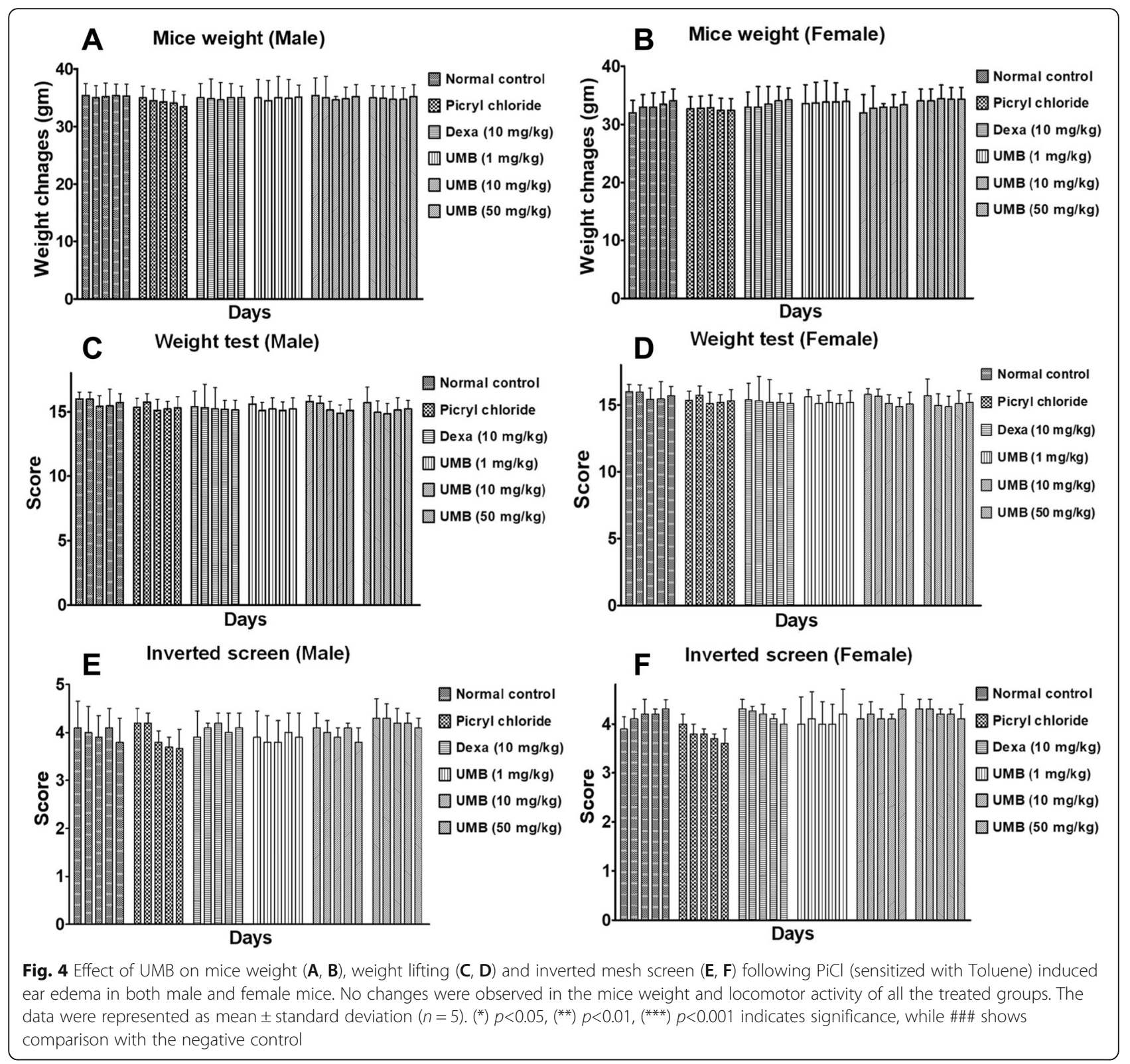

Table 1 Hematological parameters of allergic ear edema induced by PiCl+Toluene topical application

\begin{tabular}{|c|c|c|c|c|c|c|}
\hline $\begin{array}{l}\text { Hematological } \\
\text { Parameters }\end{array}$ & $\begin{array}{l}\text { Normal control (mean } \pm \\
\text { SEM) }\end{array}$ & $\begin{array}{l}\text { Picryl } \\
\text { chloride } \\
\text { (mean } \pm \text { SEM) }\end{array}$ & $\begin{array}{l}\text { Dexa }(10 \mathrm{mg} / \\
\mathrm{kg}) \\
(\mathrm{mean} \pm \mathrm{SEM})\end{array}$ & $\begin{array}{l}\text { UMB (1 mg/ } \\
\text { kg) } \\
\text { (mean } \pm \text { SEM) }\end{array}$ & $\begin{array}{l}\text { UMB }(10 \mathrm{mg} / \\
\mathrm{kg}) \\
(\mathrm{mean} \pm \mathrm{SEM})\end{array}$ & $\begin{array}{l}\text { UMB }(50 \mathrm{mg} / \\
\mathrm{kg}) \\
(\mathrm{mean} \pm \mathrm{SEM})\end{array}$ \\
\hline Eosinophil's (\%) & $0.62 \pm 0.23$ & $6.7 \pm 0.08^{\# \# \#}$ & $4.3 \pm 0.16$ & $5.70 \pm 0.34$ & $5.1 \pm 0.38^{* *}$ & $4.7 \pm 0.32^{* * *}$ \\
\hline Basophils (\%) & $0.3 \pm 0.44$ & $0.6 \pm 0.034^{\# \# \#}$ & $0.32 \pm 0.13$ & $0.5 \pm 0.42$ & $0.43 \pm 0.51^{* *}$ & $0.33 \pm 0.40^{* * * *}$ \\
\hline Neutrophils (\%) & $23.5 \pm 1.53$ & $53 \pm 0.13^{\# \# \#}$ & $31 \pm 0.36$ & $39 \pm 0.28$ & $37 \pm 0.45^{* *}$ & $34 \pm 0.45^{* * *}$ \\
\hline Monocytes (\%) & $3.5 \pm 0.07$ & $5.3 \pm 0.11^{\# \# \#}$ & $4.9 \pm 0.43$ & $5.1 \pm 0.47$ & $4.7 \pm 0.21^{* *}$ & $4.8 \pm 0.20^{* * *}$ \\
\hline WBC $\left(\times 10^{3} / \mathrm{mm}^{3}\right)$ & $2.7 \pm 0.29$ & $3.5 \pm 0.50^{\# \# \#}$ & $2.7 \pm 021$ & $2.6 \pm 0.61$ & $2.8 \pm 0.41^{* *}$ & $2.9 \pm 0.65^{* * *}$ \\
\hline
\end{tabular}

The data were represented as mean \pm standard deviation $(n=5) .\left(^{*}\right) p<0.05,\left(^{* *}\right) p<0.01,\left(^{* *}\right) p<0.001$ indicates significance, while \#\#\# shows comparison with the negative control 
Table 2 Various Biochemical Parameters were observed in PiCl+Toluene induced chronic allergic model

\begin{tabular}{lllllll}
\hline Biochemical Parameters & $\begin{array}{l}\text { Normal } \\
\text { (mean } \pm \text { SEM) }\end{array}$ & $\begin{array}{l}\text { Picryl chloride } \\
\text { (mean } \pm \text { SEM) }\end{array}$ & $\begin{array}{l}\text { Dexa }(\mathbf{1 0} \mathbf{~ m g / k g}) \\
\text { (mean } \pm \text { SEM) }\end{array}$ & $\begin{array}{l}\text { UMB (1 mg/kg) } \\
\text { (mean } \pm \text { SEM) }\end{array}$ & $\begin{array}{l}\text { UMB (10 mg/kg) } \\
\text { (mean } \pm \text { SEM) }\end{array}$ & $\begin{array}{l}\text { UMB (50 mg/kg) } \\
(\mathbf{m e a n} \pm \text { SEM) }\end{array}$ \\
\hline ALT (U/L) & $26.50 \pm 5.76$ & $28 \pm 6.99^{\# \# \#}$ & $29 \pm 7.19$ & $28 \pm 8.15$ & $27 \pm 4.33$ & $29 \pm 3.21$ \\
AST (U/L) & $70.49 \pm 8.46$ & $80.7 \pm 9.65^{\# \# \#}$ & $75.21 \pm 13.4$ & $74.38 \pm 6.99$ & $75.0 \pm 7.38$ & $74.61 \pm 8.43$ \\
Bilirubin (mg/dL) & $2.41 \pm 0.25$ & $2.67 \pm 0.15^{\# \# \#}$ & $2.39 \pm 0.20$ & $2.32 \pm 0.11$ & $2.41 \pm 0.03$ & $2.37 \pm 0.02$ \\
Creatinine (U/L) & $0.22 \pm 0.21$ & $0.25 \pm 0.34^{\# \# \#}$ & $0.23 \pm 0.03$ & $0.24 \pm 0.04$ & $0.25 \pm 0.45$ & $0.26 \pm 0.52$ \\
\hline
\end{tabular}

The data were represented as mean \pm standard deviation $(n=5) .\left(^{*}\right) p<0.05,\left(^{* *}\right) p<0.01,\left(^{* *}\right) p<0.001$ indicates significance, while \#\#\# shows comparison with the negative control

of UMB treatment on the EPO activity following ear edema induction. The negative control showed marked increase in the EPO activity, however, the UMB treatment remarkably inhibited the activity of the EPO compared to the negative control as shown in Fig. 5.

\section{Effect of UMB treatment on histological parameters}

The $\mathrm{H}$ \& $\mathrm{E}$ staining showed epidermal and dermal hyperplasia along with increase in inflammatory cells in the negative control group Fig. 9. The UMB $(50 \mathrm{mg} / \mathrm{kg}$ ) treated group showed significant improvement in the histopathology compared to the negative control.
Furthermore, the Giemsa staining was also performed to assess the eosinophilic infiltration in all the treated groups. The Giemsa staining showed a remarkable increase in the eosinophilic infiltration in the negative control group. However, the UMB treated group marginally reversed the eosinophils compared to the negative control as shown in Fig. 10.

\section{Effect of UMB on Immunohistopathological staining} Immunohistochemistry analysis revealed marked increase in the expression of iNOS protein, while attenuated the $\mathrm{Nrf} 2$ expression level in the $\mathrm{PiCl}$ treated group

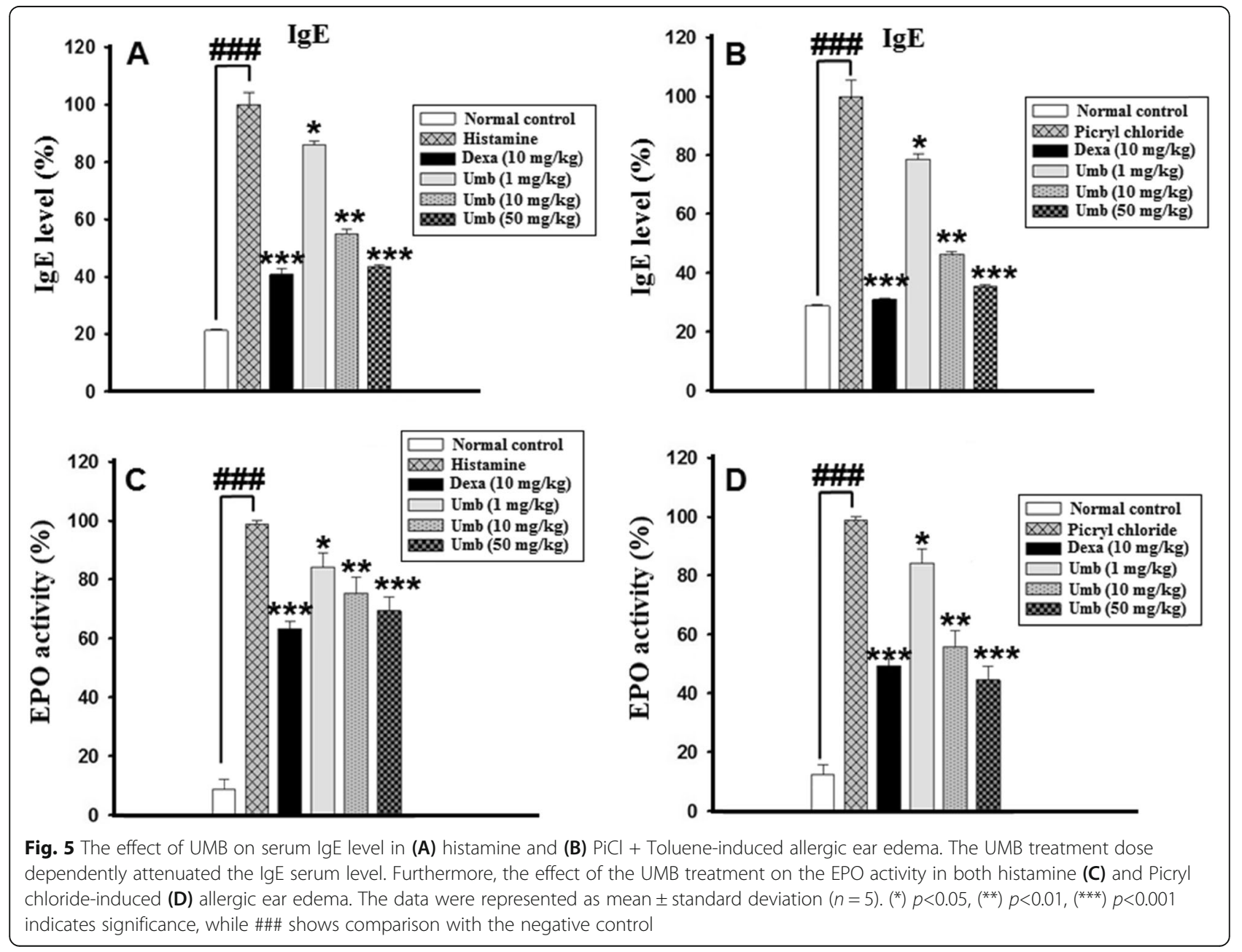




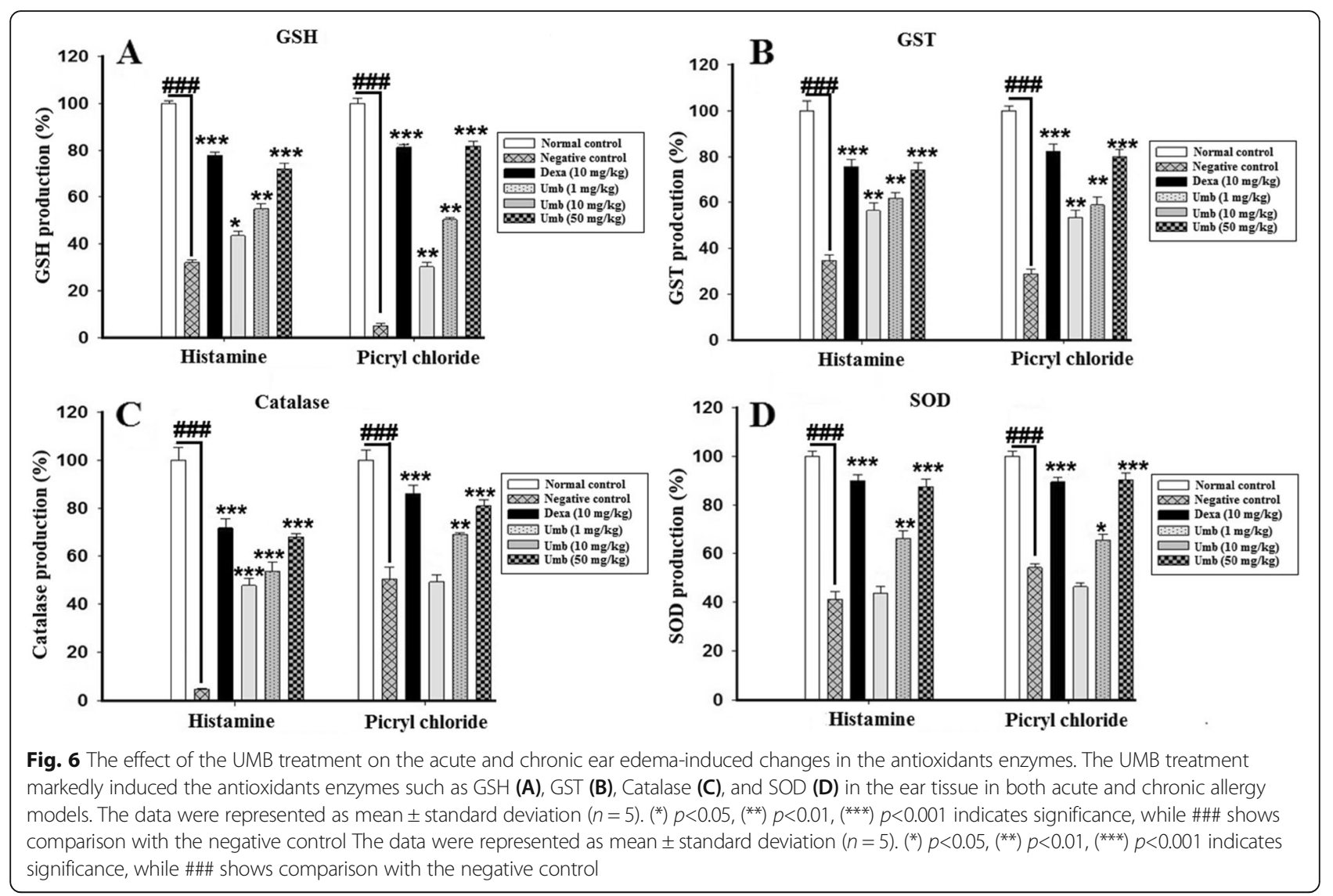

(sensitized with the Toluene). However, the UMB treatment enhanced the expression level of Nrf2 and attenuated the iNOS expression level as shown in the Fig. 6.

\section{Bioinformatics analysis}

The UMB showed marked interaction with the IL-1 $\beta$, IL-6, TNF- $\alpha$, IgE, Nrf2 and iNOS proteins via multiple hydrogen and hydrophobic bonds. The $3 \mathrm{D}$ and $2 \mathrm{D}$ structure of UMB interaction with their protein targets Figs. 11 and 12, while the number hydrogen bonds, interacting amino acids, molecular docking energy and RMSD are shown in the Table 3.

\section{Pharmacokinetics analysis}

The UMB physicochemical and pharmacokinetic analysis was determined using in silico approaches [39, 40]. The UMB showed promising physicochemical properties such as $\log \mathrm{P}$, water-solubility, lipid solubility, and drug likeness behavior. Similarly, the UMB showed encouraging bioavailability, absorption, distribution, showed metabolism via cytochrome p450 system and excretion via renal route as shown in the Fig. 13. Furthermore, the UMB portrayed promising drug likeness and medicinal chemistry properties as shown in the Fig. 13.

\section{Discussion}

Umbelliferone (UMB) is a coumarin derivative found in various parts of the plants such as flowers, roots and stem isolated from the plants of Umbelliferae family. The UMB has been reported for various biological properties such as anti-inflammatory, anti-diabetic and antifungal, however, the anti-allergic activities has not been reported yet [30]. In the current study, the UMB was investigated against both acute (histamine) and chronic (PiCl+Toluene) ear edema models in mice. The histamine is well known mediator of allergic inflammation and released when the body is hypersensitive to any substance $[31,42]$. The acute ear edema was induced by administering the histamine $(10 \mathrm{mg} / \mathrm{kg}$, i.d), while the chronic ear edema was induced by multiple topical application of the $\mathrm{PiCl}$ (sensitized with the Toluene) at the dorsal surface of ear [21, 31, 43]. During acute histamine-induced ear edema the UMB (UMB administration $30 \mathrm{~min}$ after the histamine-induced ear edema) dose dependently reduced the ear edema compared to the negative control. Similarly, the negative control showed marked increase in the ear edema following $\mathrm{PiCl}$ (sensitized with the Toluene), however, the UMB treatment dose dependently reduced the ear edema and the dose of $50 \mathrm{mg} / \mathrm{kg}$ showed maximum response. Similarly, 


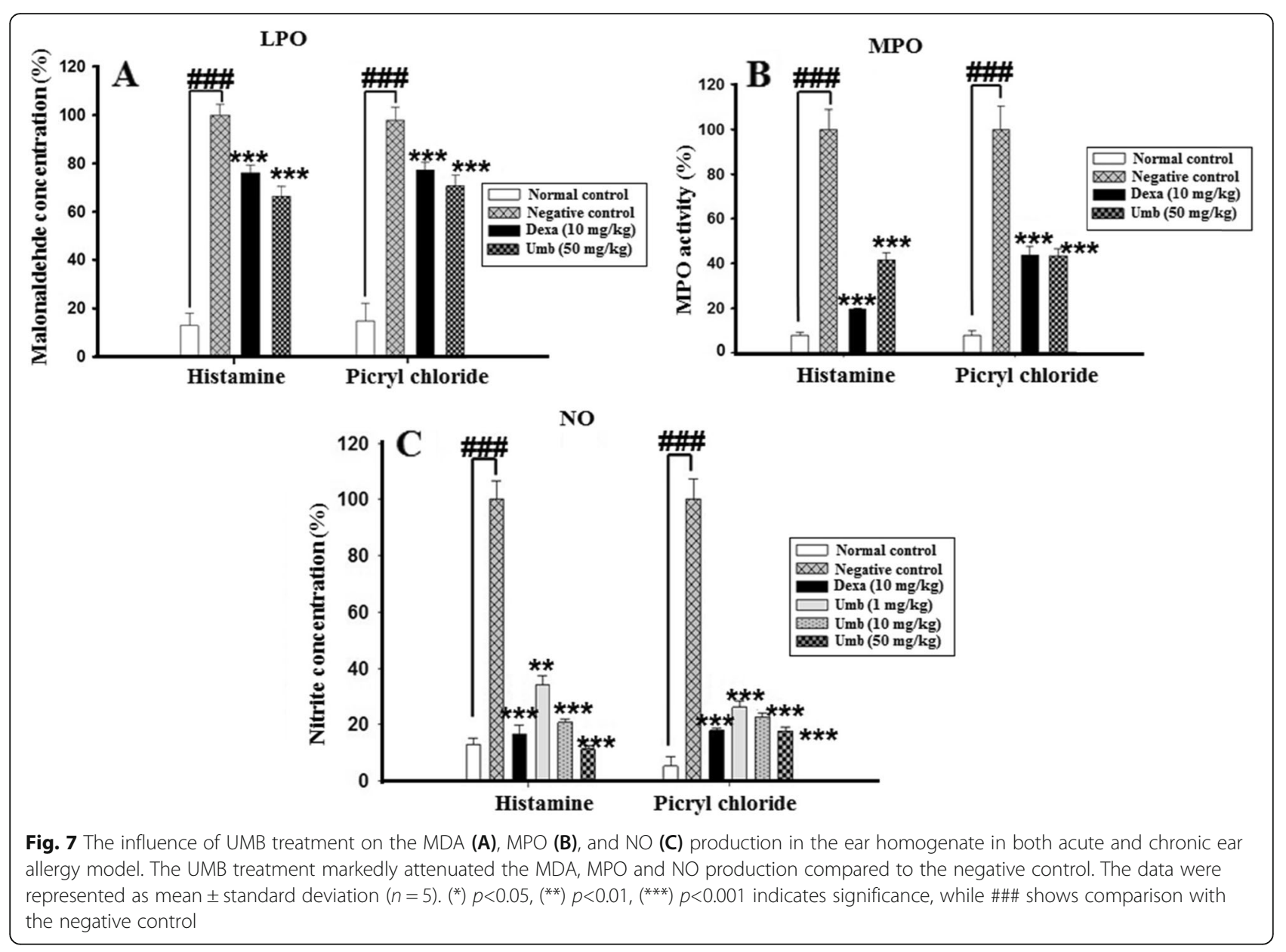

the dexamethasone also attenuated the allergic ear edema following induction of ear edema with the $\mathrm{PiCl}+$ Toluene compared to the negative control. The UMB treated group showed remarkable improvement in the behavioral parameters such as allergic clinical scoring compared to the negative control. The histamine and $\mathrm{PiCl}$ administration significantly altered the antioxidants enzymes (GST, GSH, Catalase and SOD) and oxidative stress markers i.e. MDA. While treatment with UMB markedly induced the antioxidants enzymes and neutralized the oxidative stress markers in ear homogenate compared to the negative control. The $\mathrm{NO}$ an important mediator of inflammation and influenced by the iNOS enzyme activity [44, 45]. During inflammatory and allergic conditions the $\mathrm{NO}$ concentration raised proportionally $[46,47]$. In the current study, the NO production was significantly elevated in the negative control group ( $\mathrm{PiCl}+$ Toluene induced allergy), however, the UMB treatment showed significant decrease in the NO production compared to the negative control. Similarly, the MPO activity (marker of neutrophil infiltration) raised significantly during the inflammation and allergy [48, 49]. The MPO assay was performed to assess the effect of the UMB treatment on the neutrophilic infiltration following chronic ear edema induction with the $\mathrm{PiCl}+$ Toluene $[46,48]$. The UMB treatment markedly attenuated the MPO activity compared to the negative control. Furthermore, the EPO activity indirectly indicates the eosinophils infiltration to site if injury and commonly implicated in the allergic diseases $[48,50]$. In the present study, the $\mathrm{PiCl}$ administration markedly raised the EPO concentration, however, UMB treatment significantly attenuated the EPO concentration compared to the negative control.

The changes in the hematological parameters are commonly implicated during inflammatory and allergic conditions [48, 50]. The blood complete analysis was performed to assess the effect of the UMB treatment on blood composition following ear edema induction with the $\mathrm{PiCl}+$ Toluene. The negative control showed marked elevation in both neutrophils and eosinophils count, however, the UMB treatment significantly reduced the neutrophilic and eosinophilic count in the blood and improved other hematological parameters compared to the negative control. Similarly, serum analysis was performed to investigate the changes in liver and kidney functions test following allergic ear edema induced with the $\mathrm{PiCl}+$ Toluene $[51,52]$. The LFTs and RFTs data 


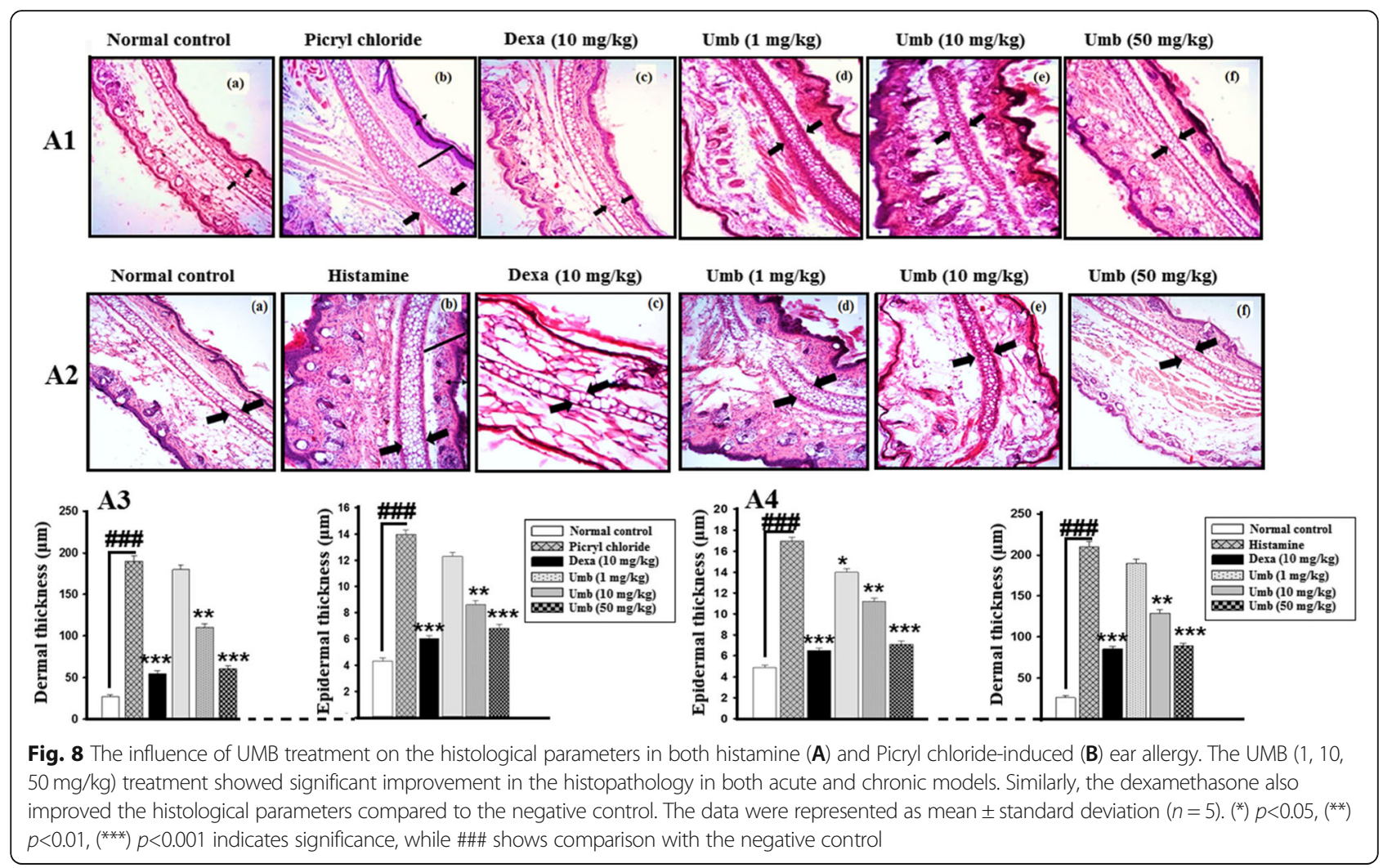

showed no observable changes in all the treated groups included UMB.

In order to evaluate the histological changes in the ear histology following induction of acute and chronic allergy and subsequently to assess the effect of the UMB treatment on the histological parameters $\mathrm{H}$ and $\mathrm{E}$ staining was performed [53]. The $\mathrm{H}$ and $\mathrm{E}$ staining showed that UMB treatment markedly reduced the epidermal edema, hypertrophy and immune cells infiltration compared to the negative control (both acute histamine and chronic PiCl+Toluene-induced allergy). Similarly, the effect of the UMB treatment on the eosinophilic infiltration to the site of allergic inflammation was studied using Giemsa staining [53, 54]. The Giemsa staining showed a significant decrease in the eosinophilic infiltration in the UMB treated group compared to the negative control. Furthermore, the positive control group treated with the dexamethasone also improved the histological parameters compared to the negative control.

Serum IgE antibodies are key marker of Type 1 hypersensitivity reaction in allergic diseases including atopic dermatitis [51]. Allergen specific IgE binds to its receptor (FceRI and FceRII or CD23) on mast and basophil cells [54]. The disparity of T helper 1 (Th1) and $\mathrm{T}$ helper 2 (Th2) cells have been reported in atopic dermatitis with the dominancy of the $\mathrm{T}$ helper
2 responses, which leads to the increase production of IgE antibodies [54]. For this purpose, levels of IgE were analyzed in both acute and chronic allergy models. The UMB treatment markedly reduced the serum IgE level compared to the negative control. The computational tools are attracting the attention of the researchers and serves to assess the mechanism of interaction of the ligand with protein targets. The computational analysis solved many mysteries associated with the interaction of ligand and proteins $[47,55]$. In the current study, the computational analysis was used to assess the mechanism and validate the interaction of the ligand with the protein targets. The UMB interacted with the protein targets via multiple hydrogen bonds and hydrophobic bonds. Similarly, the molecular docking interaction of the ligand with the protein targets was also validated. The immunohistochemistry was performed to assess the effect of the UMB treatment on the expression level of iNOS and Nrf2 protein following allergy induction with the $\mathrm{PiCl}+$ Toluene $[52,55]$. The negative control group showed marked decrease in the expression of Nrf2, while showed significant increase in the iNOS proteins. However, the UMB treatment markedly attenuated the iNOS protein expression and induced Nrf2 expression compared to the negative control. 

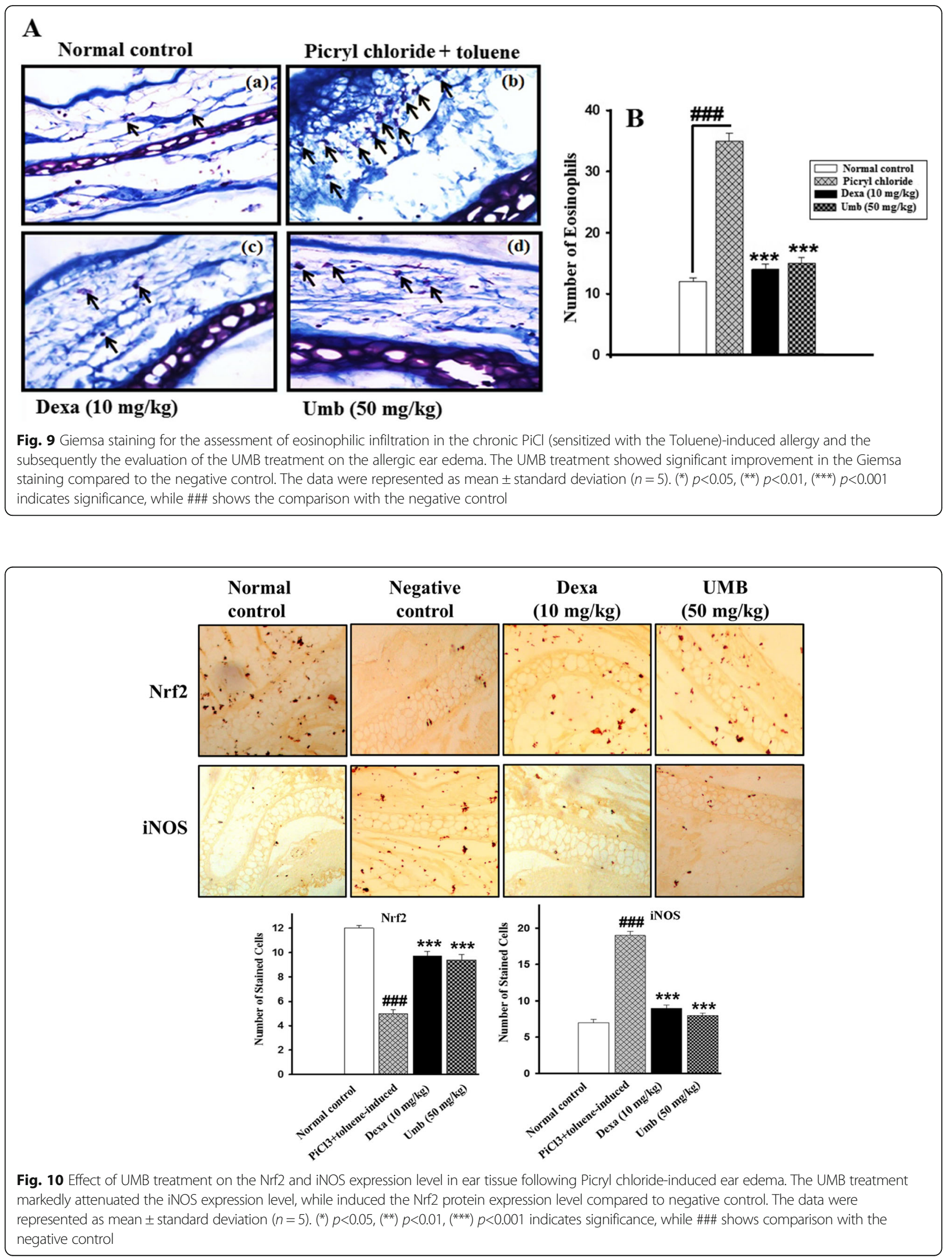


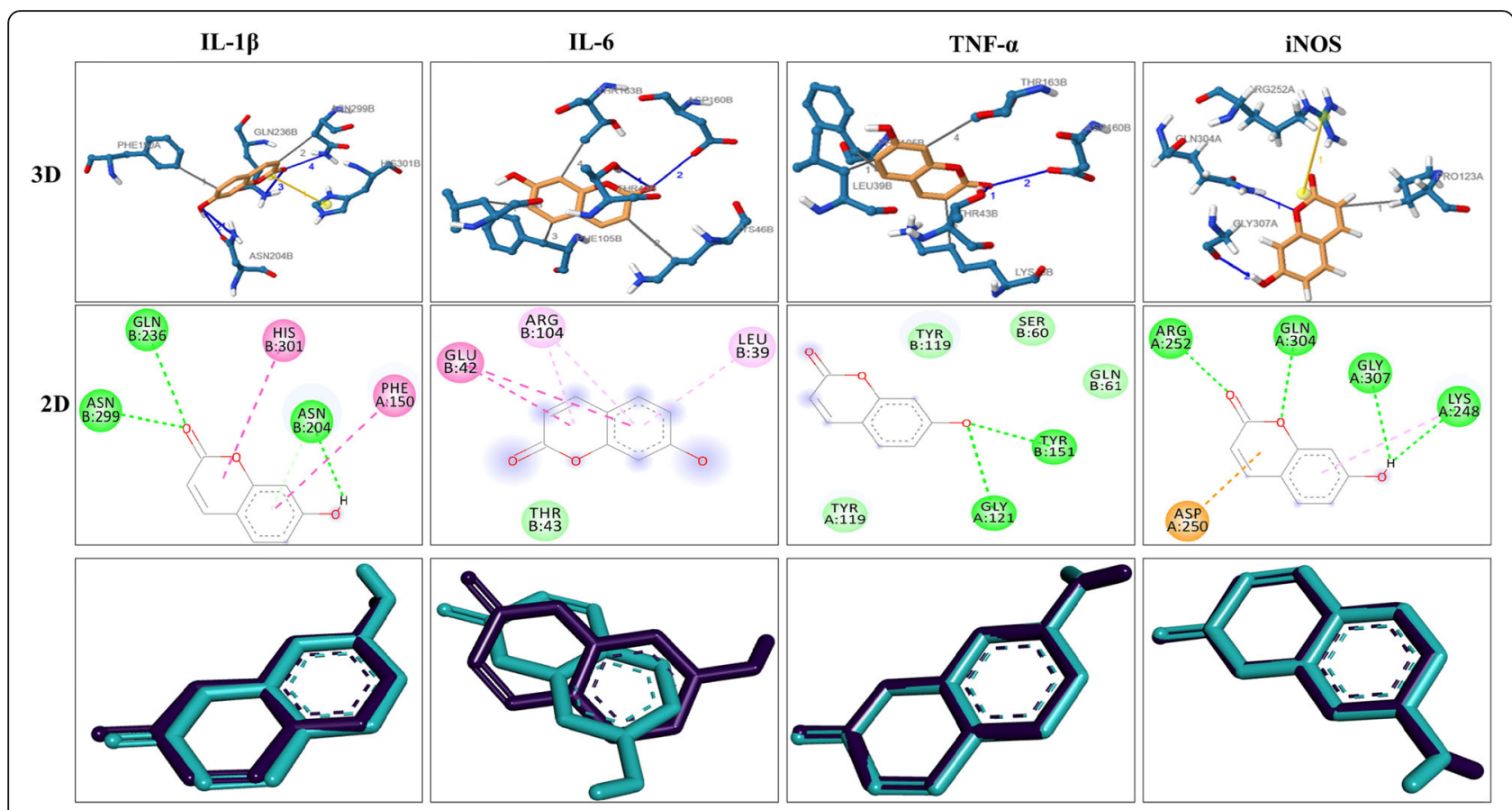

Fig. 11 Determination of compatibility of UMB at various target sites (IL-1 $\beta, I L-6$ and TNF-a) involved in the process of allergic inflammation through Auto-Dock and MOE. The yellow colour shows UMB (ligand), while the light magenta colour shows the active site residues. The interacting amino acids are shown as green sticks. The 3D, 2D and docking validation structures are exhibited respectively

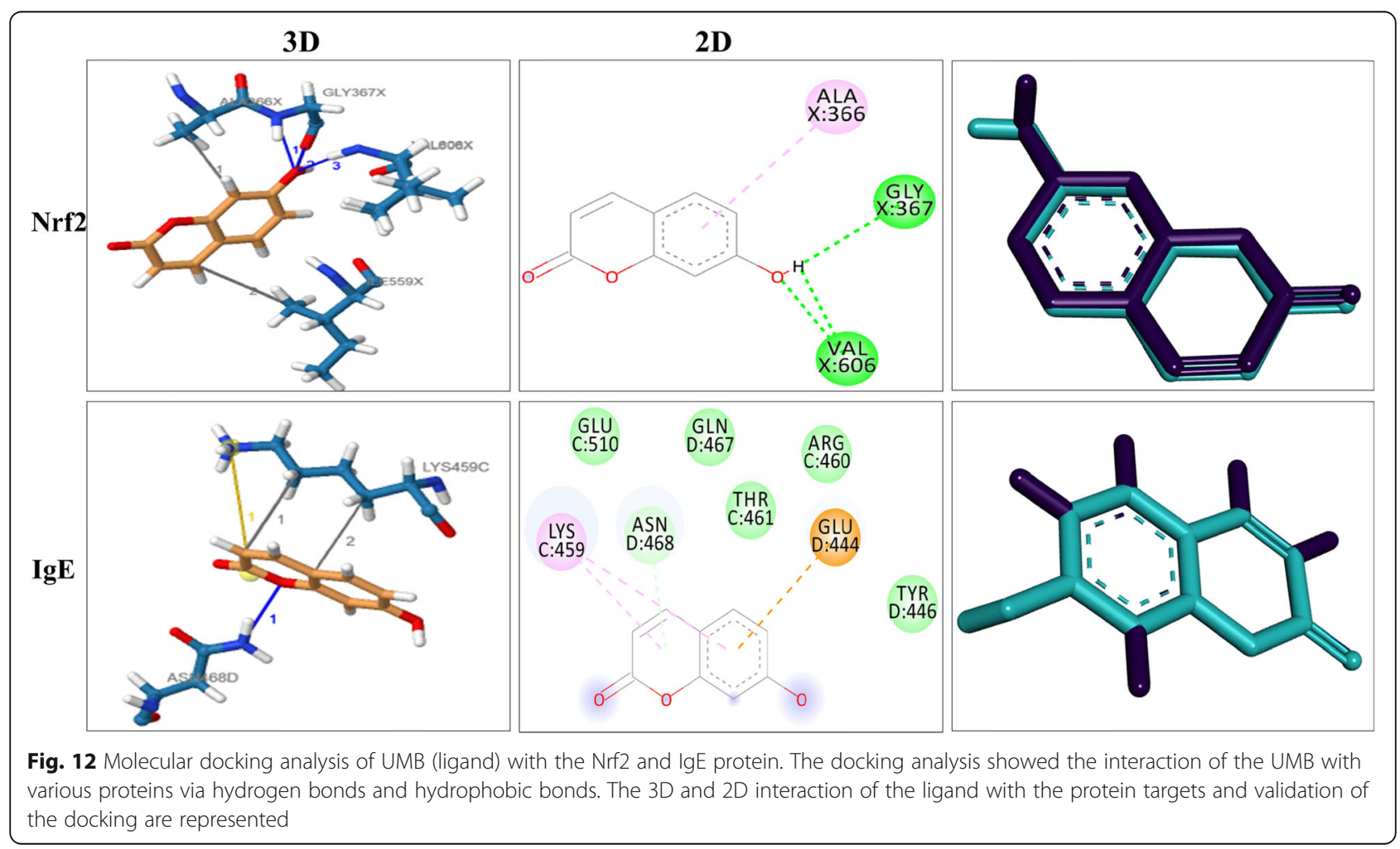


Table 3 The docking interaction of the UMB with various protein targets

\begin{tabular}{llllll}
\hline Proteins & PDB ID & RMSD $(\AA)$ & H-bonds amino acids & H-bonds numbers & Binding energies (kcallmol) \\
\hline TNF-a & $2 \mathrm{az} 5$ & 0.319 & Gly121, Tyr151 & 2 & -6.9 \\
IL-1 $\boldsymbol{\beta}$ & $1 \mathrm{itb}$ & 0.289 & Asn204, Gln236, Asn299 & 3 & -7.3 \\
IL-6 & $1 \mathrm{p} 9 \mathrm{~m}$ & 1.21 & & & -6.3 \\
iNOS & $1 \mathrm{dd} 7$ & 0.308 & Lys248, Gly307, Gln304, Arg252 & 4 & -6.8 \\
Nrf2 & 2flu & 0.230 & Gly367, Val606, Ala666 & 3 & -6.7 \\
IgE & 4grg & 0.254 & Asn468 & 1 & -6.8 \\
\hline
\end{tabular}

\section{Conclusion}

The current study evaluated the anti-allergic activity of the UMB against both acute histamine- and chronic $\mathrm{PiCl}$ (sensitized with Toluene)-induced ear edema. The UMB treatment markedly attenuated the ear edema and ear weight compared to the negative control. The UMB treatment induced the antioxidants enzymes and attenuated the oxidative stress markers. The UMB treatment significantly improved the histological parameters and reduced the immune cells infiltration to the site of

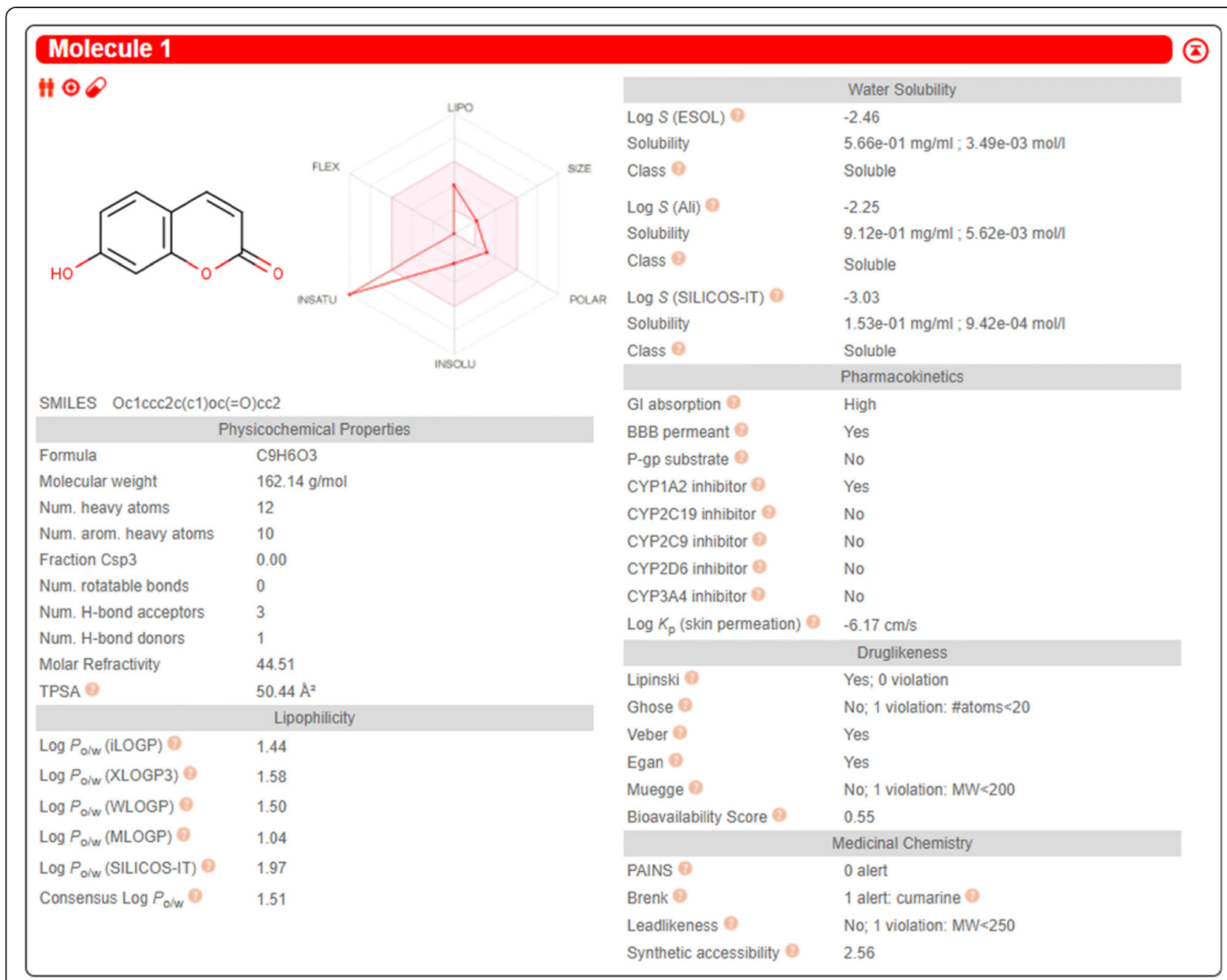

Fig. 13 The pharmacokinetic assessment of the UMB using in silico approaches. The Swiss target prediction online software was used to assess the pharmacokinetic parameters of the UMB. The various properties that were taken into consideration include physicochemical properties, liophilicity, water-solubility, pharmacokinetics, drug-likeness and medicinal chemistry aspects. The UMB overall showed better pharmacokinetic and physicochemical behavior 
allergic inflammation. The UMB reduced the iNOS expression, while induced the expression of Nrf2 proteins. In short, the UMB treatment significantly reduced the allergic ear edema and improved the sign and symptoms associated with the histamine and $\mathrm{PiCl}$ (sensitized with Toluene)-induced ear edema.

\section{Abbreviations}

UMB: Umbelliferone; PiCl: Picryl chloride; Nrf2: Nuclear factor erythroid 2related factor 2; TNF-a: Tumor necrosis factor-a; GST: Glutathione Stransferases; MPO: Myeloperoxidase; EPO: Eosinophil peroxidase; NO: Nitric oxide; SOD: Sulphur oxide dismutase; LPO: Lipid peroxidase; HO1: Hemeoxygenase-1; MDA: Malonaldehde; IL-6: Interleukin 6; IL$1 \beta$ : Interleukin-1 $\beta$; iNOS: Inducible nitric oxide synthase

\section{Acknowledgments}

We greatly acknowledge Prof Yeong Shik Kim, Emiritus Professor, College of Pharmacy, Seoul National University, Seoul, Korea for providing Umbelliferone (purity 99.9\%).

\section{Authors' contributions}

$Y$ and AUK perform the in vivo, biochemical assays and molecular docking analysis. EKS, SK, AO and OS design the study. SK, OS, AO and EKS analyzed the results. Y, AUK and SK drafted the manuscript. SK supervised the project. All the authors read and approved the final manuscript.

\section{Funding}

The current study was supported by the Higher education commission (HEC, Pakistan) Pakistan, under the SRGP project number (No. 357 SRGP/HEC/2014). The funding body provided the financial support only and no other assistance was provided.

\section{Availability of data and materials}

The data presented in this study are confined and described within the article and will be disseminated by the corresponding author upon request. All materials used in this study were included in methods section adequately.

\section{Declarations}

\section{Ethical approval and consent to participate}

The study was approved by the ethical committee of the Quaid-i-Azam University, Islamabad under approval number BEC-FBS-QAU2019-181. All the animal experiments were performed according to the institutional ethical committee for care and handling of experimental animals.

\section{Consent for publications}

Not applicable.

\section{Competing interests}

The author declares no conflict of interest.

\section{Author details}

1Pharmacological Sciences Research Lab, Department of Pharmacy, Faculty of Biological Sciences, Quaid-i-Azam University Islamabad, Islamabad, Pakistan. ${ }^{2}$ Department of Pharmacy, Abdul Wali Khan University, Mardan, Pakistan. ${ }^{3}$ College of Pharmacy, Ewha Womans University, 52, Ewhayeodae-gil, Seodaemun-gu, Seoul 03760, South Korea. ${ }^{4}$ Department of Pharmacognosy, Faculty of Pharmacy, Ankara University, Ankara, Turkey.

\section{Received: 6 December 2020 Accepted: 29 July 2021}

Published online: 27 August 2021

\section{References}

1. Lim SK, Kwon M-S, Lee J, Oh YJ, Jang J-Y, Lee J-H, et al. Weissella cibaria WIKIM28 ameliorates atopic dermatitis-like skin lesions by inducing tolerogenic dendritic cells and regulatory T cells in BALB/c mice. Sci Rep. $2017 ; 7(1): 1-9$
2. Lee $\mathrm{JH}$, Cho $\mathrm{SH}$. Korean red ginseng extract ameliorates skin lesions in $\mathrm{NC}$ / Nga mice: an atopic dermatitis model. J Ethnopharmacol. 2011;133(2):810-7. https://doi.org/10.1016/j.jep.2010.11.020.

3. Akdis CA, Akdis M. Mechanisms and treatment of allergic disease in the big picture of regulatory T cells. J Allergy Clin Immunol. 2009;123(4):735-46. https://doi.org/10.1016/j.jaci.2009.02.030.

4. Ramesh B, Pugalendi K. Impact of umbelliferone (7-hydroxycoumarin) on hepatic marker enzymes in streptozotocin diabetic rats. Indian J Pharmacol. 2006;38(3):209.

5. Kitagaki H, Fujisawa S, Watanabe K, Hayakawa K, Shiohara T. Immediate-type hypersensitivity response followed by a late reaction is induced by repeated epicutaneous application of contact sensitizing agents in mice. J Investig Dermatol. 1995;105(6):749-55.

6. Chun J, Choi RJ, Khan S, Lee D-S, Kim Y-C, Nam Y-J, et al. Alantolactone suppresses inducible nitric oxide synthase and cyclooxygenase-2 expression by down-regulating NF-kB, MAPK and AP-1 via the MyD88 signaling pathway in LPS-activated RAW 264.7 cells. Int Immunopharmacol. 2012; 14(4):375-83. https://doi.org/10.1016/j.intimp.2012.08.011.

7. Khan AM, Khan AU, Ali H, Islam SU, Seo EK, Khan S. Continentalic acid exhibited nephroprotective activity against the LPS and E coli-induced kidney injury through inhibition of the oxidative stress and inflammation. Int Immunopharmacol. 2020;80:106209.

8. Ishita IJ, Islam MN, Kim YS, Choi RJ, Sohn HS, Jung HA, et al. Coumarins from Angelica decursiva inhibit lipopolysaccharide-induced nitrite oxide production in RAW 264.7 cells. Arch Pharm Res. 2016;39(1):115-26. https:// doi.org/10.1007/s12272-015-0668-6

9. Ramu RS, Shirahatti P, Zameer F, Lakkappa Dhananjaya B, NP MN. Correction: assessment of in vivo antidiabetic properties of umbelliferone and lupeol constituents of banana (musa sp. var. nanjangud rasa bale) flower in hyperglycaemic rodent model. Plos One. 2016;11(7):e0160048.

10. Muthu R, Selvaraj N, Vaiyapuri M. Anti-inflammatory and proapoptotic effects of umbelliferone in colon carcinogenesis. Hum Exp Toxicol. 2016; 35(10):1041-54. https://doi.org/10.1177/0960327115618245.

11. Yu SM, Hu DH, Zhang JJ. Umbelliferone exhibits anticancer activity via the induction of apoptosis and cell cycle arrest in HepG2 hepatocellular carcinoma cells. Mol Med Rep. 2015;12(3):3869-73. https://doi.org/10.3892/ mmr.2015.3797.

12. Sana E, Zeeshan M, Ain QU, Khan AU, Hussain I, Khan S, et al. Topical delivery of curcumin-loaded transfersomes gel ameliorated rheumatoid arthritis by inhibiting NF-k $\beta$ pathway. Nanomedicine. 2021;16(10):819-37. https://doi.org/10.2217/nnm-2020-0316.

13. Islam MN, Choi RJ, Jin SE, Kim YS, Ahn BR, Zhao D, et al. Mechanism of antiinflammatory activity of umbelliferone 6-carboxylic acid isolated from Angelica decursiva. J Ethnopharmacol. 2012;144(1):175-81. https://doi.org/1 0.1016/j.jep.2012.08.048.

14. Ouyang L, Dan Y, Shao Z, Yang S, Yang C, Liu G, et al. Effect of umbelliferone on adjuvant-induced arthritis in rats by MAPK/NF-KB pathway. Drug Design Dev Ther. 2019;13:1163.

15. Luo H, Fan Z, Xiang D, Jiang Z, Zhang W, Gao L, et al. The protective effect of umbelliferone ameliorates myocardial injury following ischemiareperfusion in the rat through suppression NLRP3 inflammasome and upregulating the PPAR- $\gamma$. Mol Med Rep. 2018;17(2):3404-10. https://doi. org/10.3892/mmr.2017.8208.

16. Germoush MO, Othman SI, Al-Qaraawi MA, Al-Harbi HM, Hussein OE, AlBasher $\mathrm{G}$, et al. Umbelliferone prevents oxidative stress, inflammation and hematological alterations, and modulates glutamate-nitric oxide-cGMP signaling in hyperammonemic rats. Biomed Pharmacother. 2018;102:392402. https://doi.org/10.1016/j.biopha.2018.03.104.

17. Ali H, Khan A, Ali J, Ullah H, Khan A, Ali H, et al. Attenuation of LPS-induced acute lung injury by continentalic acid in rodents through inhibition of inflammatory mediators correlates with increased Nrf2 protein expression. BMC Pharmacol Toxicol. 2020;21(1):1-14.

18. Subramaniam SR, Ellis EM. Neuroprotective effects of umbelliferone and esculetin in a mouse model of Parkinson's disease. J Neurosci Res. 2013; 91(3):453-61. https://doi.org/10.1002/jnr.23164.

19. Hayes JD, Dinkova-Kostova AT. The Nrf2 regulatory network provides an interface between redox and intermediary metabolism. Trends Biochem Sci. 2014;39(4):199-218. https://doi.org/10.1016/j.tibs.2014.02.002.

20. Kanimozhi G, Prasad NR, Ramachandran S, Pugalendi KV. Umbelliferone modulates gamma-radiation induced reactive oxygen species generation 
and subsequent oxidative damage in human blood lymphocytes. Eur J Pharmacol. 2011;672(1-3):20-9. https://doi.org/10.1016/j.ejphar.2011.09.003.

21. Afridi R, Khan AU, Khalid S, Shal B, Rasheed H, Ullah MZ, et al. Antihyperalgesic properties of a flavanone derivative Poncirin in acute and chronic inflammatory pain models in mice. BMC Pharmacol Toxicol. 2019; 20(1):1-16.

22. Fan H-J, Xie Z-P, Lu Z-W, Tan Z-B, Bi Y-M, Xie L-P, et al. Anti-inflammatory and immune response regulation of Si-Ni-san in 2, 4-dinitrochlorobenzeneinduced atopic dermatitis-like skin dysfunction. J Ethnopharmacol. 2018;222: 1-10. https://doi.org/10.1016/j.jep.2018.04.032.

23. Shal B, Khan A, Naveed M, Ali H, Seo EK, Choi H, et al. Neuroprotective effect of 25-Methoxyhispidol a against CCl4-induced behavioral alterations by targeting VEGF/BDNF and caspase-3 in mice. Life Sci. 2020;253:117684. https://doi.org/10.1016/j.lfs.2020.117684.

24. Satoh T, Chen QJ, Sasaki G, Yokozeki H, Katayama I, Nishioka K. Cyclophosphamide-induced blood and tissue eosinophilia in contact sensitivity: mechanism of hapten-induced eosinophil recruitment into the skin. Eur J Immunol. 1997;27(1):85-91. https://doi.org/10.1002/eji.18302 70113.

25. Koh K, Pearce A, Marshman G, Finlay-Jones J, Hart PH. Tea tree oil reduces histamine-induced skin inflammation. Br J Dermatol. 2002;147(6):1212-7. https://doi.org/10.1046/j.1365-2133.2002.05034.x.

26. Brand C, Townley S, Finlay-Jones J, Hart P. Tea tree oil reduces histamineinduced oedema in murine ears. Inflamm Res. 2002;51(6):283-9. https://doi. org/10.1007/PL00000305.

27. Ramu R, Shirahatti PS, Zameer F, Ranganatha LV, Prasad MN. Inhibitory effect of banana (Musa sp. var. Nanjangud rasa bale) flower extract and its constituents Umbelliferone and Lupeol on a-glucosidase, aldose reductase and glycation at multiple stages. S Afr J Bot. 2014;95:54-63. https://doi.org/1 0.1016/j.sajb.2014.08.001.

28. Ramu R, Shirahatti PS, Zameer F, Lakkapa DB, Nagendra M. Evaluation of Banana (Musa sp. var. Nanjangud rasa bale) flower and pseudostem extracts on antimicrobial, cytotoxicity and thrombolytic activities. Int J Pharm Pharm Sci. 2015;7:136-40

29. Khalid S, Khan A, Shal B, Ali H, Kim YS, Khan S. Suppression of TRPV1 and P2Y nociceptors by honokiol isolated from Magnolia officinalis in 3rd degree burn mice by inhibiting inflammatory mediators. Biomed Pharmacother. 2019;114: 108777. https://doi.org/10.1016/j.biopha.2019.108777.

30. Farombi $\mathrm{E}$, Adelowo $\mathrm{O}$, Ajimoko Y. Biomarkers of oxidative stress and heavy metal levels as indicators of environmental pollution in African cat fish (Clarias gariepinus) from Nigeria Ogun River. Int J Environ Res Public Health. 2007:4(2):158-65. https://doi.org/10.3390/ijerph2007040011.

31. Doherty V, Ogunkuade O, Kanife U. Biomarkers of oxidative stress and heavy metal levels as indicators of environmental pollution in some selected fishes in Lagos, Nigeria. Am Eurasian J Agric Environ Sci. 2010;7(3):359-65.

32. Khan AU, Khan A, Khan A, Shal B, Aziz A, Ahmed MN, et al. Inhibition of NFKB signaling and HSP70/HSP90 proteins by newly synthesized hydrazide derivatives in arthritis model. Naunyn Schmiedeberg's Arch Pharmacol. 2021;1497-519.

33. Cheng JB, Pillar JS, Shirley JT, Showell HJ, Watson JW, Cohan VL. Antigenmediated pulmonary eosinophilia in immunoglobulin G1-sensitized guinea pigs: eosinophil peroxidase as a simple specific marker for detecting eosinophils in bronchoalveolar lavage fluid. J Pharmacol Exp Ther. 1993; 264(2):922-9.

34. Khan A, Shal B, Khan AU, Ullah R, Baig MW, Seo EK, et al. Suppression of TRPV1/TRPM8/P2Y nociceptors by Withametelin via downregulating MAPK signaling in mouse model of vincristine-induced neuropathic pain. Int J Mol Sci. 2021;22(11):6084. https://doi.org/10.3390/ijms22116084.

35. Khan S, Shehzad O, Cheng M-S, Li R-J, Kim YS. Pharmacological mechanism underlying anti-inflammatory properties of two structurally divergent coumarins through the inhibition of pro-inflammatory enzymes and cytokines. J Inflamm. 2015;12(1):47. https://doi.org/10.1186/s12950-015-0087-y.

36. Khan A, Ullah MZ, Afridi $R$, Rasheed $H$, Khalid S, Ullah $H$, et al. Antinociceptive properties of 25-methoxy hispidol a, a triterpinoid isolated from Poncirus trifoliata (Rutaceae) through inhibition of NF-KB signalling in mice. Phytother Res. 2019;33(2):327-41. https://doi.org/10.1002/ptr.6223.

37. Mazimba O. Umbelliferone: sources, chemistry and bioactivities review. Bull Fac Pharm Cairo Univ. 2017;55(2):223-32. https://doi.org/10.1016/j.bfopcu.2 017.05.001.

38. Ikezawa Y, Nakazawa M, Tamura C, Takahashi K, Minami M, Ikezawa Z. Cyclophosphamide decreases the number, percentage and the function of
CD25+ CD4+ regulatory T cells, which suppress induction of contact hypersensitivity. J Dermatol Sci. 2005;39(2):105-12. https://doi.org/10.1016/j. jdermsci.2005.02.002.

39. Hirasawa N, Ohsawa Y, Katoh G, Shibata K, Ishihara K, Seyama T, et al. Modification of the picryl chloride-induced allergic dermatitis model in mouse ear lobes by 12-0-tetradecanoylphorbol 13-acetate, and analysis of the role of histamine in the modified model. Int Arch Allergy Immunol. 2009;148(4):279-88. https://doi.org/10.1159/000170381.

40. Khalid S, Zahid MA, Ali H, Kim YS, Khan S. Biaryl scaffold-focused virtual screening for anti-aggregatory and neuroprotective effects in Alzheimer's disease. BMC Neurosci. 2018;19(1):74. https:/doi.org/10.1186/s12868-018-0472-6.

41. Harada D, Takada C, Tsukumo Y, Takaba K, Manabe H. Analyses of a mouse model of the dermatitis caused by 2, 4, 6-trinitro-1-chlorobenzene (TNCB)repeated application. J Dermatol Sci. 2005;37(3):159-67. https://doi.org/10.1 016/j.jdermsci.2004.11.007

42. Ali J, Khan AU, Shah FA, Ali H, Islam SU, Kim YS, et al. Mucoprotective effects of Saikosaponin-a in 5-fluorouracil-induced intestinal mucositis in mice model. Life Sci. 2019;239:116888. https:/doi.org/10.1016/j.lfs.2019.116888.

43. Ojala T, Remes S, Haansuu P, Vuorela H, Hiltunen R, Haahtela K, et al. Antimicrobial activity of some coumarin containing herbal plants growing in Finland. J Ethnopharmacol. 2000;73(1-2):299-305. https://doi.org/10.1016/ S0378-8741(00)00279-8.

44. Hoult J, Payá M. Pharmacological and biochemical actions of simple coumarins: natural products with therapeutic potential. Gen Pharmacol. 1996;27(4):713-22. https://doi.org/10.1016/0306-3623(95)02112-4.

45. Ullah H, Khan A, Baig MW, Ullah N, Ahmed N, Tipu MK, et al. Poncirin attenuates CCL4-induced liver injury through inhibition of oxidative stress and inflammatory cytokines in mice. BMC Complement Med Ther. 2020;20:1-14.

46. Haig TJ, Haig TJ, Seal AN, Pratley JE, An M, Wu H. Lavender as a source of novel plant compounds for the development of a natural herbicide. J Chem Ecol. 2009;35(9):1129-36. https://doi.org/10.1007/s10886-009-9689-2.

47. Khalid S, Ullah MZ, Khan AU, Afridi R, Rasheed H, Khan A, et al. Antihyperalgesic properties of honokiol in inflammatory pain models by targeting of NF-kB and Nrf2 signaling. Front Pharmacol. 2018;9:140. https:// doi.org/10.3389/fphar.2018.00140.

48. Schoepe S, Schäcke H, May E, Asadullah K. Glucocorticoid therapy-induced skin atrophy. Exp Dermatol. 2006;15(6):406-20. https://doi.org/10.1111/j. 0906-6705.2006.00435.x.

49. Khan AU, Khan AM, Khan A, Shal B, Aziz A, Ahmed MN, et al. The newly synthesized compounds (NCHDH and NTHDH) attenuates LPS-induced septicemia and multi-organ failure via $\mathrm{Nrf2/HO1}$ and HSP/TRVP1 signaling in mice. Chem Biol Interact. 2020;329:109220. https://doi.org/10.1016/j.cbi.202 0.109220 .

50. Banerji N, Maiti M, Sem S, Datta P. Pharmacognosy of Aegle marmelos (L) Correa. Seed. A new protein source. Acta Pharm Hung. 1982;52(3):97-101.

51. Niture SK, Khatri R, Jaiswal AK. Regulation of Nrf2-an update. Free Radic Biol Med. 2014;66:36-44. https://doi.org/10.1016/j.freeradbiomed.2013.02.008.

52. Rasheed $\mathrm{H}$, Afridi $\mathrm{R}$, Khan AU, Ullah MZ, Khalid S, Atiq A, et al. Antiinflammatory, anti-rheumatic and analgesic activities of 2-(5-mercapto-1, 3, 4-oxadiazol-2-yl)-N-propylbenzenesulphonamide (MOPBS) in rodents. Inflammopharmacology. 2018;26(4):1037-49. https://doi.org/10.1007/s10787018-0446-4.

53. Mahmoud AM, Wilkinson FL, Jones AM, Wilkinson JA, Romero M, Duarte J, et al. A novel role for small molecule glycomimetics in the protection against lipid-induced endothelial dysfunction: involvement of Akt/eNOS and Nrf2/ARE signaling. Biochim Biophys Acta Gen Subjects. 2017;1861(1):3311-22.

54. Mahmoud AM, Wilkinson F, Jones AM, Wilkinson JA, Romero M, Duarte J, et al. A novel role for small molecule glycomimetics in the protection against lipidinduced endothelial dysfunction. Heart. 2015;101(Suppl):3311-22.

55. Ullah MZ, Khan AU, Afridi R, Rasheed H, Khalid S, Naveed M, et al. Attenuation of inflammatory pain by puerarin in animal model of inflammation through inhibition of pro-inflammatory mediators. Int Immunopharmacol. 2018;61:30616. https://doi.org/10.1016/j.intimp.2018.05.034.

\section{Publisher's Note}

Springer Nature remains neutral with regard to jurisdictional claims in published maps and institutional affiliations. 